\title{
モリブデン粉末の水への溶出試験
}

\author{
加藤 昌宏的 1 , 林憲二放, 吉田 政幹敌, 福田 政則乱 4 , 荒木 敏春的 5 ,

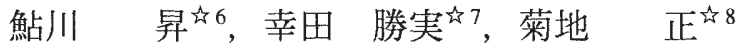 \\ ム1㫼アライドマテリアル， テ931-8543 富山市岩瀬古志町 2. \\ 的2株アライドタングステン， 干 931-8543 富山市岩瀬古志町 2. \\ ↔3パナソニック梾ライティング社，干 569-1193 高梘市幸町 1-1。 \\ 虹 4 日本新金属(森)，广 561-0829 豊中市千成町 1-6-64. \\ 社 5 東芝ナノアナリシス(侏)，干 235-8522 横浜市磯子区新杉田町 8. \\ ^ ${ }^{2}$ 日本タングステン(侏)，テ841-0203 佐賀県三養基郡基山町大字園部 3173-2.

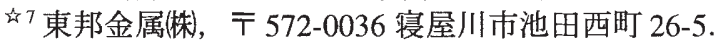 \\ 的 8 山口東京理科大学, 干 756-0884 山陽小野田市大学通 1-1-1.
}

\section{Molybdenum Powder Elution Behavior to Water}

\author{
Masahiro Katoh $^{\text {t } 1}$, Kenji Hayashi ${ }^{\text {is }}$, Masayoshi Yoshida ${ }^{\text {t } 3}$, Masanori Fukuda ${ }^{\text {i } 4}$, Toshiharu Araki ${ }^{\text {t5 } 5}$, \\ Noboru Ayukawa ${ }^{\text {tr } 6}$, Katsumi Koda ${ }^{\text {tr } 7}$ and Tadashi Kikuchi ${ }^{\text {th } 8}$ \\ 41 A.L.M.T. Corp., 2 Iwasekoshi-machi, Toyama 931-8543, Japan. \\ is 2 A.L.M.T. Tungsten Corp., 2 Iwasekoshi-machi, Toyama 931-8543, Japan. \\ ${ }^{2}$ Panasonic Corporation, 1-1 Saiwai-cho, Takatsuki 569-1193, Japan. \\ ${ }^{4} 4$ Japan New Metals Co., Ltd., 1-6-64 Sennari-cho, Toyonaka 561-0829, Japan. \\ 초 5 Toshiba Nanoanalysis Corporation, 8 Shinsugita-cho, Isogo-ku, Yokohama 235-8522, Japan \\ ${ }^{2}{ }^{6}$ Nippon Tungsten Co., Ltd., 3173-2 Sonobe, Kiyama-cho, Miyaki-gun, Saga 841-0203, Japan. \\ ${ }_{47}^{7}$ Toho Kinzoku Co., Ltd., 26-5 Ikedanishi-machi, Neyagawa 572-0036, Japan. \\ ${ }^{8}$ Tokyo University of Science in Yamaguchi, 1-1-1 Daigaku-dori, Sanyo-Onoda 756-0884, Japan.
}

Received January 29, 2010

\section{SYNOPSIS}

The press process of molybdenum is done without using an organic binder when the molybdenum is manufactured at high temperature used in powder metallurgy. The decrease in the molybdenum ingot density, which was a factor in the yield decrease of the molybdenum product, is occurred because of remaining moisture and the presence of molybdenum oxide in molybdenum metal powder. To clarify the cause of the yield decrease, the uniform distribution process of the rare earth salt by wet doping into molybdenum and the molybdenum elution to water were examined. The dopants provide a unique effect on the thermal-deformation resistance of molybdenum. In solvents of purified water and tap water, the amount of elution of molybdenum was examined as dependence on molybdenum particle sizes and the temperatures of the solvent. Moreover, elution results obtained using alkali and acid water solvents were compared. As a result, it can be suggested that a steady dope manufacturing condition can be obtained by using the metallic molybdenum or $\mathrm{MoO}_{2}$ as the raw powder, as well as by the use of purified water held at a low temperature.

\section{KEY WORDS}

molybdenum powder, doping, elution behavior in water, yield decrease, high density

\section{1 緒言}

モリブデン金属は高融点であるため主に粉末冶金工程によ り製造されている. 本法は熱間加工時の緻密化不足を抑止す る目的から，一部焼結製品以外では有機バインダーフリーに てプレスを行う.また，水分やモリブデン酸化物の混入はモ リブデンの緻密化不足の原因になるため,これら残留物がな
いように留意する必要がある.なお焼結は, 緻密化のために 真空中か, 水素雾囲気中にて行われる.

金属モリブデンは主に炉部材などの耐熱材料として用いら れている. 更に耐変形特性を有する材料に関しては, 高温使 用時に金属組織が等軸で粗大化する結晶成長を抑制し繊維状 組織を維持する目的から希土類酸化物を分散しモリブデンの 
変形抑制を行う ${ }^{1.2)}$.この合金製造に関しては, モリブデン酸 化物またはモリブデン金属粉末に水を溶媒として希土類酸化 物またはその原料となる希土類塩などを $1 \mathrm{mass} \%$ 程度モリブ デンに添加し均一分散させる. その後, 通常は還元を行い, 純 モリブデンの場合と同様にプレス工程から焼結, 加工の工程 を経る. 以上のモリブデン製造工程の概略を Fig.1に示した.

この工程は通常, 閉鎖系で水とモリブデン粉末を均一に 混合後, 1 日程度の乾燥を行っているため, モリブデン投入 量の変化はないが, 微視的に見ると水へのモリブデン溶出や 乾燥時の析出が起こり, 意図しないモリブデン微細粒子の生 成や析出粒子が凝集しモリブデン酸化物の残留が生ずる.ま た，モリブデンの析出によるネッキングを起こした凝集粒子 は, プレスの際にも空隙を保持してしまうような状況を新た に生じ, プレス体密度および焼結密度を低下させ，それ以降 の加工工程での製造歩留を悪化させてしまう等の問題を生ず る.

従来の水へのモリブンデン溶出に関する研究は, (1)合成土 壌からの溶出試験として液固比を変更した溶出量比較 ${ }^{3)}$, (2) 水溶液中でのモリブデン形態が 6 価のモリブデンの活性炭を 用いた分離浱縮の実験から $\mathrm{pH}$ の影響や共存イオンの影響に

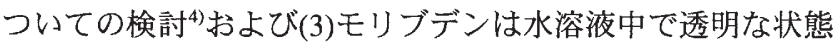
であれば $\mathrm{MoO}_{4}{ }^{2-}$ の状態であり, ブルーを呈する状態は, 平均 酸化状態が 5 価と 6 価の間にあるような化合物, $\mathrm{MoO}_{2}(\mathrm{OH})$, $\mathrm{MoO}_{2.5}(\mathrm{OH})_{0.5}$ 等である ${ }^{5,6)}$ 旨, 報告されているのみである.

本研究では, 製品の歩留まり低下の原因を明らかにする目 的から水を溶媒とし希土類塩をモリブデンに添加する均一分 散化工程に着目した. 本工程は耐変形モリブデン特有の工程 であり, 水分やモリブデン酸化物の混入は緻密化不足を生ず るため, 水へのモリブデン溶出について検討を行った. 水と

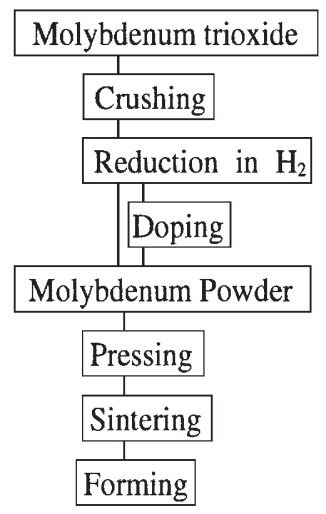

Fig.1 Manufacturing process of molybdenum.
モリブデンの反応は, ドープ工程に限らずモリブデン製造に おける水への溶出を考慮するためにも興味深いにもかかわら ず現在まで系統的に検討が行われなかった．そこでこれらの 知見を得るために種々の実験を行って, モリブデンが水に溶 出する際の温度，粒度，およびドープ溶液に投入する可能性 のある酸, アルカリなどに関する溶出量の影響を明らかにし， ドープ工程を始め, 将来的な種々の工程に対応した検討を 行った.

\section{2 試料および実験方法}

試料はアライドマテリアル製でフィッシャ一法による平均 粒径が 0.94, 2.0, 3.0, 5.0 および $7.3 \mu \mathrm{m}$ の金属モリブデン粉末 および酸化モリブデン粉末を用いた.これらの比表面積(BET 值) および酸素値を Table 1 に示した. 尚, 本試料中酸素含有 率は水素雾囲気中で $1000^{\circ} \mathrm{C}$ に 30 分加熱, 還元し，その直後 の重量と還元前の重量の差から算出した。

モリブデン粉末の SEM (日立製作所製 S-4200)によるモ フォロジーを Fig. 2 に示した。平均粒径が $2 \mu \mathrm{m}$ 以下の微細な TMO-10およびTMO-20では一次粒子に球状でなく針状の粒 子が含まれ，いずれの金属モリブデン粉末も二次粒子として の凝集が見られる.これらに比較すると酸化モリブデン粉末 には二次粒子の凝集は見られない. $\mathrm{MoO}_{2}$ および $\mathrm{MoO}_{3}$ 粉末は XRD およびTG-DTAにより結晶構造および酸素の組成比を 確認し，正確に4価，6価であることを確認した．

酸性溶液はドープ溶液にドープ剂を溶解する際に可能性の ある塩酸 $(\mathrm{HCl})$, 硝酸 $\left(\mathrm{HNO}_{3}\right)$, 硫酸 $\left(\mathrm{H}_{2} \mathrm{SO}_{4}\right)$ をそれぞれ水道 水, 純水にて水素イオン濃度を $\mathrm{pH} 3$ に希釈調製した. また, アルカリ溶液も同様にドープ溶液を中和する際に使用する可 能性のある水酸化ナトリウムを水道水, 純水で $\mathrm{pH} 9$ に希釈調 製し実験に供した。

尚, 水道水は一般の水道からの水であるのに対し, 純水は イオン交換樹脂により純化した水を用いた．このように純水 はイオン交換水であるため, 中性粒子の除去は行われていな い.ここでの純水は $\mathrm{pH} 7.9$, 水道水は $\mathrm{pH} 7.3$ であった. また, タニタ製EW-510で塩素濃度を測定した結果, 水道水では 0.3 $\mathrm{mg} / \mathrm{L}$ の塩素濃度であるのに対し, 純水は $0.0 \mathrm{mg} / \mathrm{L}$ で測定限界 以下の濃度であった。

水へのモリブデン溶出を検討するために初期値を求める必 要があり, モリブデン粉末 $1.0 \mathrm{~g}\left(\mathrm{MoO}_{3}\right.$ 粉末の場合は $\left.1.5 \mathrm{~g}\right)$ を $1 \mathrm{~L}$ の水に入れて，スターラで 0.5 時間摚找し， 1 時間放置し て静沈させてから, 水に含まれるモリブデン濃度を初期値と した。この值を初期值としないと，その後の放置時間におけ

Table 1 Mean particle size and oxygen content of molybdenum powders.

\begin{tabular}{|c|c|c|c|c|c|}
\hline GRADE & TMO-10 & TMO-20 & TMO-30 & TMO-50 & HDM \\
\hline Mean particle size $/ \mu \mathrm{m}$ & 0.94 & 2.0 & 3.0 & 5.0 & 7.3 \\
\hline BET $/ \mathrm{m}^{2} \mathrm{~g}^{-1}$ & 2.99 & 0.57 & 0.42 & 0.18 & 0.12 \\
\hline Oxygen content $/ \%$ & 0.56 & 0.14 & 0.08 & 0.04 & 0.04 \\
\hline
\end{tabular}



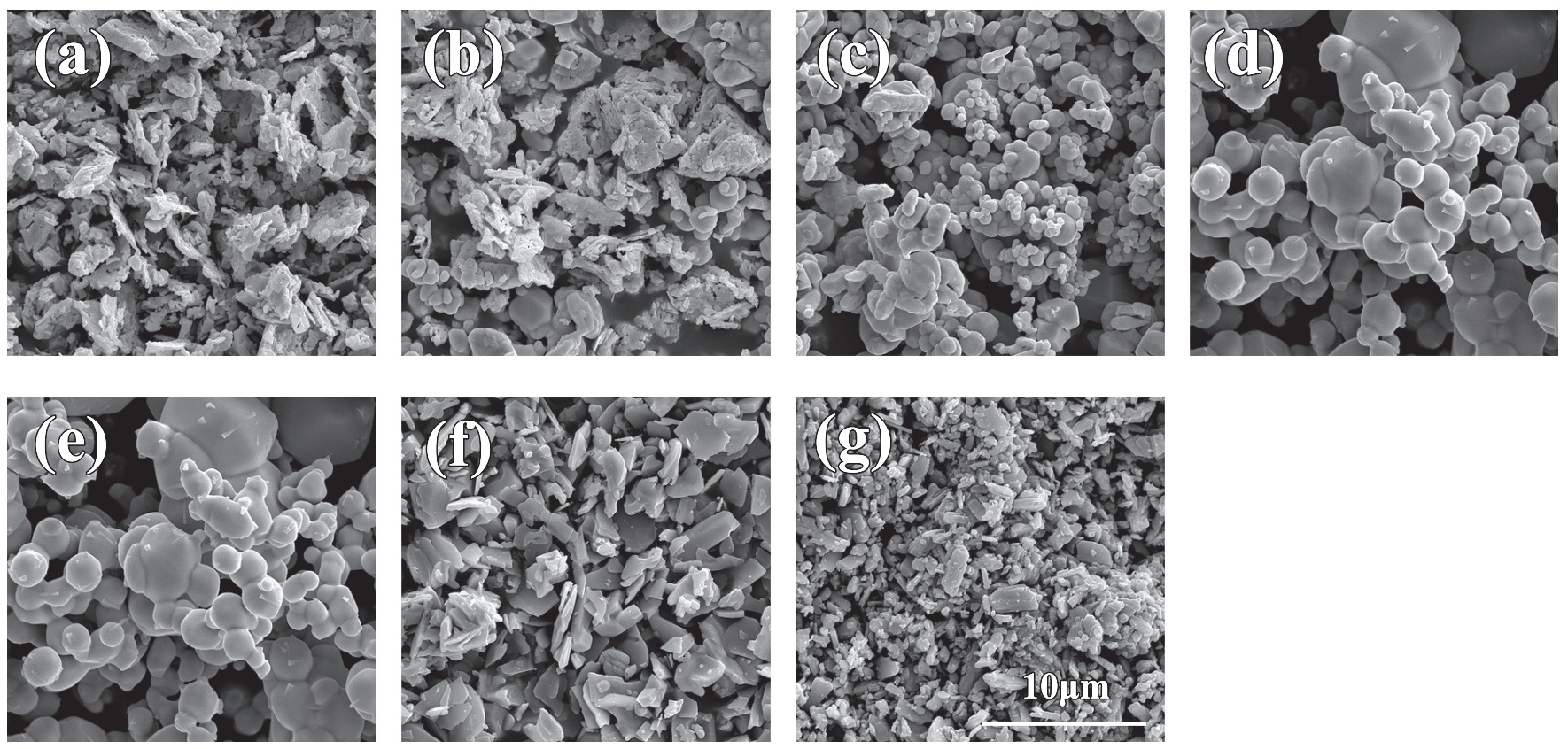

Fig.2 SEM micrographs of molybdenum and molybdenum oxide powders.

(a) TMO-10, (b) TMO-20, (c) TMO-30, (d) TMO-50, (e) HDM, (f) $\mathrm{MoO}_{2}$, (g) $\mathrm{MoO}_{3}$.

る溶出量との相関を得ることができないからである．水温， $\mathrm{pH}, \mathrm{Mo}$ 濃度の測定は静沈後に行った. 試料の放置時間は 1 時 間，1週間毎に1ヶ月までの経時変化について検討を行った. モリブデンの溶出量は, 溶出後の上澄み水を ICP 発光分光分 析装置(島津製作所製ICP-8100)にてJIS K 0102 の手順で測定 した.

溶出抑制の効果を確認するために用いた試薬類は $\mathrm{HCl}$, $\mathrm{HNO}_{3}, \mathrm{H}_{2} \mathrm{SO}_{4}$, 水酸化ナトリウム $(\mathrm{NaOH})$, 炭酸水素ナトリウ ム $\left(\mathrm{NaHCO}_{3}\right)$ ，炭酸ナトリウム $\left(\mathrm{Na}_{2} \mathrm{CO}_{3}\right)$ ，塩化ナトリウム $(\mathrm{NaCl})$, 硝酸ナトリウム $\left(\mathrm{NaNO}_{3}\right)$, 硫酸ナトリウム $\left(\mathrm{Na}_{2} \mathrm{SO}_{4}\right)$, 過マンガン酸カリウム $\left(\mathrm{KMnO}_{4}\right)$, アスコルビン酸 $\left(\mathrm{C}_{6} \mathrm{H}_{8} \mathrm{O}_{6}\right)$, 酸 化マンガン $\left(\mathrm{MnO}_{2}\right)$, 炭酸カルシウム $\left(\mathrm{CaCO}_{3}\right)$, 塩化カルシウ $厶\left(\mathrm{CaCl}_{2}\right)$, 酸化亜鈶 $(\mathrm{ZnO})$, 酢酸鉆 $\left(\mathrm{Pb}\left(\mathrm{OCOCH}_{3}\right)_{2}\right)$ で, すべ て和光純薬製でグレードがあるものは全て JIS 試薬特級であ る. 試薬特級のない試薬のみ, $\mathrm{MnO}_{2}, \mathrm{~Pb}\left(\mathrm{OCOCH}_{3}\right)_{2}$ は化学用 Practical Grade を, $\mathrm{HCl}, \mathrm{HNO}_{3}, \mathrm{H}_{2} \mathrm{SO}_{4}$ は精密分析用 Super Special Grade を用いた.

\section{3 溶出条件の検討}

モリブデンから純水への溶出量に関し, 粒径別について検 討を行った。 その結果を 1 時間放置と 1 週間放置を合わせて Fig.3に示した.これよりBET值が1桁大きくなると, 溶出量 も 1 桁大きくなることが判り，両対数において直線的な関係 となった. $3 \sim 5 \mathrm{~mm}$ の切削片の检討を行った結果，溶出量は $2.4 \mathrm{mg} / \mathrm{L}$ であり, 粉末に比較して 1 枌以上低值であった。ま た，モリブデン板 $\left(1 \times 50 \times 50 \mathrm{~mm}^{3}\right)$ を用い同様の実験を行っ たところ溶出量は定量下限以下であった。

以上の結果, BET值 $2.99,0.57,0.42,0.18$ および $0.12 \mathrm{~m}^{2} / \mathrm{g}$ の

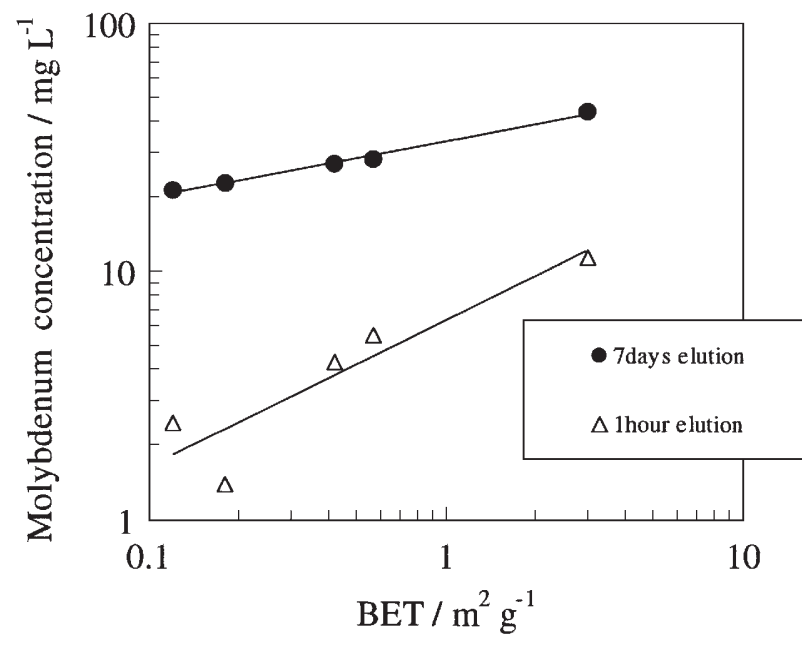

Fig.3 Relation between molybdenum mean particle size and elution concentration soak in purified water after an hour and seven days. $1 \mathrm{~g}$ molybdenum powders were soak in one liter purified water.

粉末に対して各々の溶出量は 1 時間放置後には $11.3,5.5,4.3$, 1.4 および $2.5 \mathrm{mg} / \mathrm{L} て ゙, 1$ 週間後には 43.6, 28.3, 27.2, 22.6およ び21.2 mg/Lとなり, 粒度が細かいほど溶出量は多くなり,特に BET 值 $2.99 \mathrm{~m}^{2} / \mathrm{g}$ である $0.94 \mu \mathrm{m}$ の粒度では溶出量が $43.6 \mathrm{mg} / \mathrm{L}$ と大幅な高値を示した. 当然ながら, 比表面積の大きな微細 な粉末ほど，溶出量が多い結果となった．1時間放置よりも 1 週間放置のほうが傾きが小さくなり, 粒度に対しては放置 時間が短いほうが粒度と溶出量の関係に敏感であることが判 る. また， 1 時間の放置では直線からのばらつきが大きいこ とが判った.このことから, 以降の実験では金属モリブデン 
粉末として標準的で一般的に用いられている平均粒径 $3.0 \mu \mathrm{m}$ の粉末を用いた。

\section{4 実験結果および考察}

溶出条件の検討の結果より(1)水温の違い, (2)純水之水道水, (3)酸化価数, (4) $\mathrm{pH}$ によるモリブデンの溶出量について比較 検討を行った。

\section{1 水温の影響}

異なった水温による純水への溶出量の結果を Fig.4 に示し た.これより水温が高いほど, 溶出量が大きくなる傾向が確 認できた. 初期では水温による溶出量の違いは3〜 4.5 mg/Lと 1.5 倍以内で少なかったが, 例えば水温が $5^{\circ} \mathrm{C}$ と $40^{\circ} \mathrm{C}$ では 7 日 経過後の溶出量に3倍の違いが生じることが判った. また, 各 温度とも溶出量は直線的に増加するため, 溶出期間が長くな ればなるほど, 溶出量の差は大きくなった。約 $20^{\circ} \mathrm{C}$ 程度の温 度差で 2 倍以上の溶出量の差になる傾向が判った. また, 以降 の結果でも示すように, いずれの溶出量も当初は直線的に溶 出量が増加するが，長期にわたることで溶出量の増加が緩や かに飽和する傾向にある. $40^{\circ} \mathrm{C}$ や室温での溶出では当初の直 線的な傾向のみが見られているが，もつと長期の溶出試験を 行うことで溶出は鈍化すると考えられる. 乾燥の際には蒸発 促進のために加熱する場合が多いが, 溶出防止のためには真 空乾燥などの手段で短時間での乾燥を検討することが有用で ある.

\section{2 純水と水道水}

水に含まれる不純物の影響を検討するために純水と水道水 の比較検討を以下に行った. Fig.5には純水と水道水について 放置時間に対する溶出量と $\mathrm{pH}$ の関係を示した。また，モリ ブデン投入前の純水, 水道水にそれぞれ含まれるモリブデン 濃度は検出限界である $0.01 \mathrm{mg} / \mathrm{L}$ 以下であった. 溶出量を実線 として左軸に示し, $\mathrm{pH}$ の推移を破線で示し右軸とした. 溶出 量は試験期間である 1ヶ月の範囲ではほぼ直線的に上昇する 傾向にあり，pH はいずれも低下した。

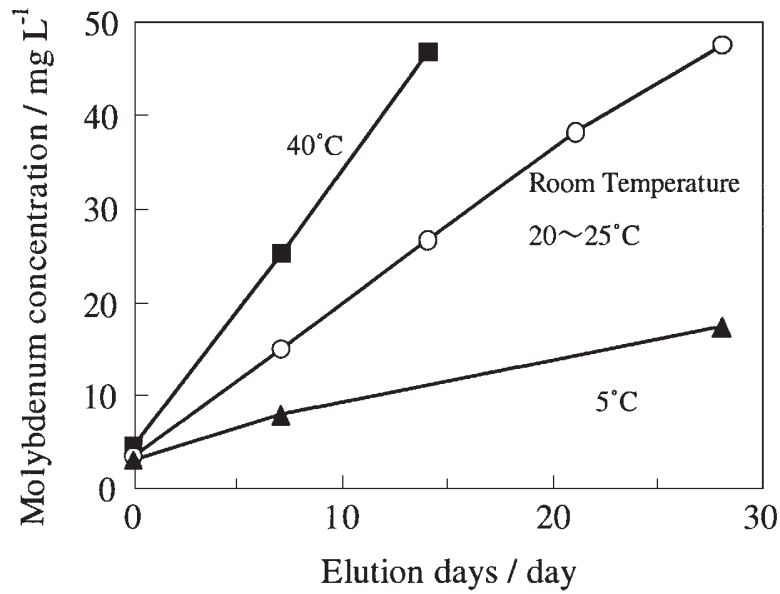

Fig.4 Difference of elution concentration in purified water at different temperatures.
溶出直後の水道水は $\mathrm{pH}$ が 6.7 から 4.7 に 1 週間で急激に酸 性化した. $\mathrm{pH}$ の変化は純水の方が敏感であり，より酸性側に シフトしている. 半面, 水道水の方が純水に比較して溶出量 が 2 倍以上大きい. 以上の結果, 溶出量を抑制するには水道 水よりも純水が適していることが示唆できた.

4.3 モリブデン金属，酸化物との違い

Fig.6にモリブデン酸化物およびモリブデンの放置時間に対 する溶出量を示した. $\mathrm{MoO}_{3}$ では初期から $300 \mathrm{mg} / \mathrm{L}$ 以上の溶 出が起こり，1ヶ月後には飽和する傾向にあった. それに比較 して金属モリブデンや $\mathrm{MoO}_{2}$ の溶出はわずかで, 直線的に 徐々に増えていく様子がわかった。

これから, $\mathrm{MoO}_{3}$ 粉末は $\mathrm{Mo}, \mathrm{MoO}_{2}$ に比較して溶出量が多 く, 特に水道水での $\mathrm{MoO}_{3}$ 粉末は 1 ケ月で投入粉末の $95 \%$ が 溶出した. 0 価と 4 価の酸化物は溶出量が少ないのに対して, 6価の $\mathrm{MoO}_{3}$ は 10 倍程度の大きな溶出量であった．通常，混 合工程では 0 価または 4 価のモリブデンを用いるが，経験的

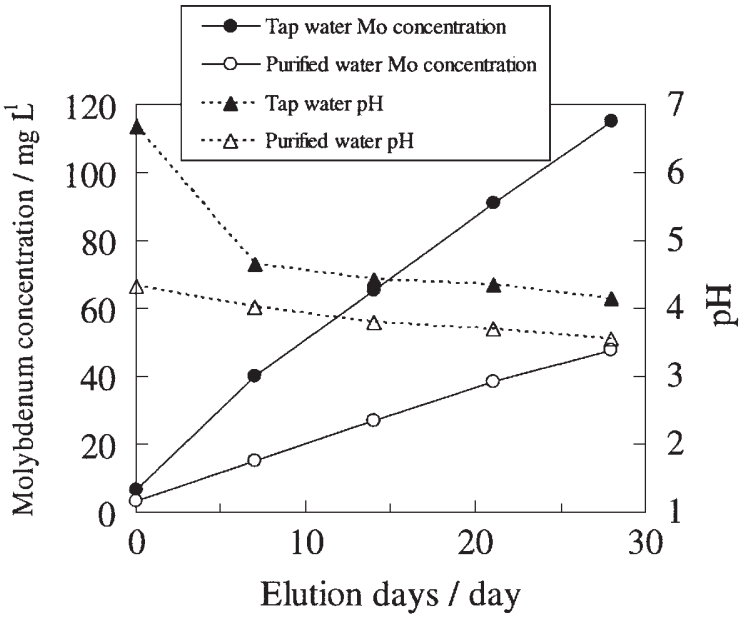

Fig.5 Relationship among elution concentration, $\mathrm{pH}$ trend of tap and purified water

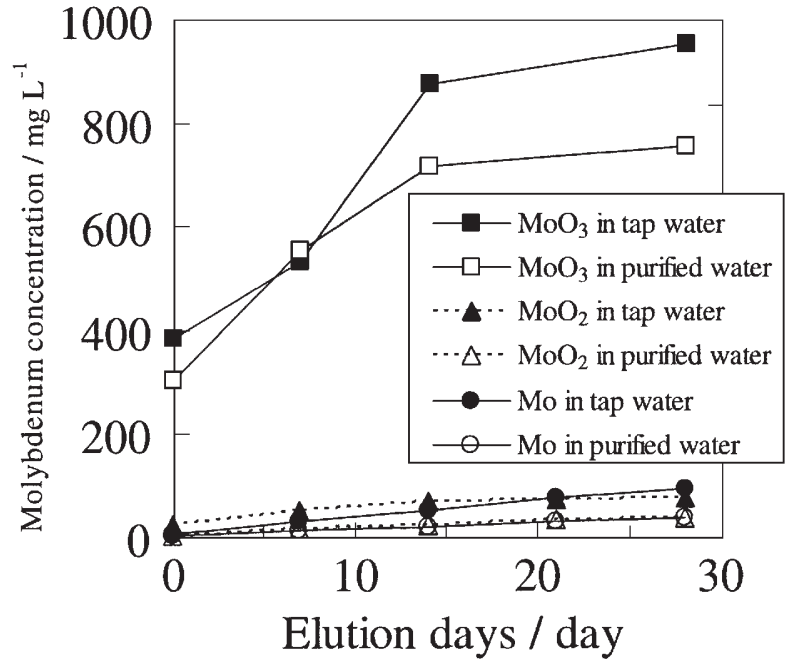

Fig.6 Relationship among elution concentration, molybdenum and molybdenum oxides. 
にもドープ工程において 6価の $\mathrm{MoO}_{3}$ を用いないことの理由 と考えられる。

\section{4 粉末投入量と溶出濃度}

純水中での放置日数と粉末投入量に対する溶出量の関係を Fig.7に示した. 粉末投入量が多くなれば当然溶出量は多くな り，放置日数に対して溶出量は1ケ月の範囲であれ机，直線 的に近い状態で増加している.Fig.8では粉末投入量を対数表 示し濃度の関係をプロットしなおした。このプロットにより モリブデン粉末の投入量の $1 / 2$ 乗に対して溶出量が比例して 高くなることが明らかになった。

4.5 酸, アルカリ，塩などの溶媒に対する溶出

ドープ工程に関し, 酸およびアルカリ溶媒中への溶出量に ついて検討を行った。

その結果を Fig.9〜 10 に示した. 酸性溶液の場合，水道水 にて希积した酸は，溶出量が水道水のみに比較して約 $2 / 3$ 低 值を示し, $\mathrm{pH}$ の変化はほとんど見られなかった. 純水に対し

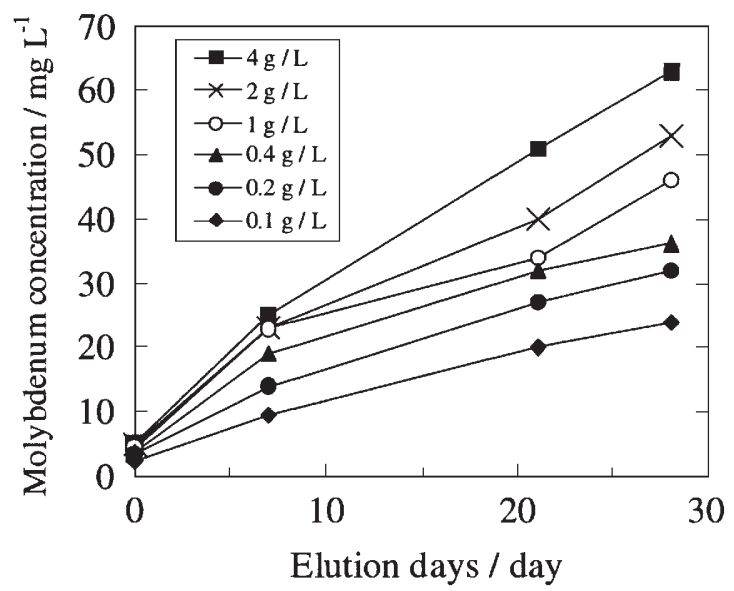

Fig.7 Relation between molybdenum input and elution concentration soak in purified water.

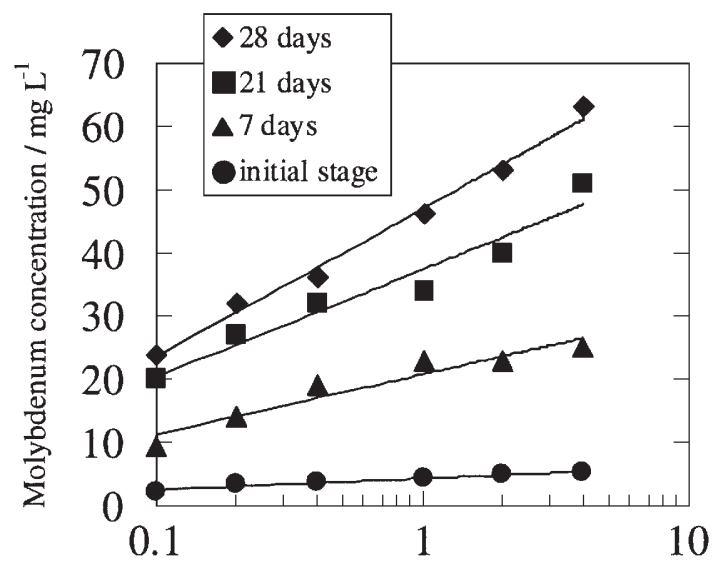

Square root of molybdenum powder input $/ \mathrm{g}^{1 / 2} \mathrm{~L}^{-1 / 2}$

Fig. 8 Relation between square root of molybdenum input and elution concentration soak in purified water ( $\mathrm{x}$-axis is a logarithmic scale).
ては溶出抑制の変化はほとんど見られなかった. Fig.10のア ルカリ溶液への溶出は, 酸溶液に比較して溶出しやすい傾向 を示した. 水素イオン濃度に関しては塩基性からすぐに酸性側 へ変化し溶出前の水素イオン濃度, $\mathrm{pH} 9$ が試験開始直後には $\mathrm{pH} 4.6$ となり 2 週間後には $\mathrm{pH} 3.7$ の結果となった. 実効的に は酸性溶液中で溶出量が多くなる傾向を示した。2週間後の 溶出量で純水の場合に $26.7 \mathrm{mg} / \mathrm{L}$ に対して, $55.3 \mathrm{mg} / \mathrm{L}$ と溶出 量が倍増している。

同様にドープ工程では最終的には焼結時に酸化物となる塩 を投入する場合が多いため，塩に対する溶出の結果を Fig.11

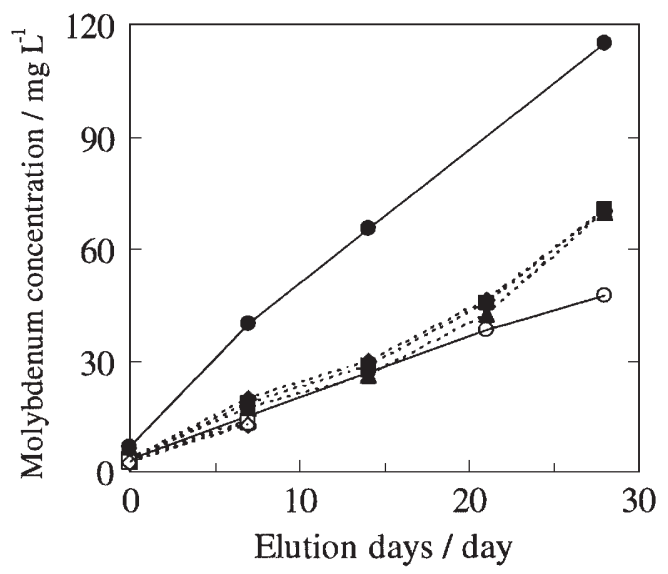
- Tap water
$\bigcirc$ - Purified water
.... Tap water, $\mathrm{HCl} \quad \cdots \Delta \cdot \cdot$ Purified water, $\mathrm{HCl}$
..-. Tap water, $\mathrm{HNO}_{3} \quad$-..-.. Purified water, $\mathrm{HNO}_{3}$
$\cdots \leftrightarrow$ Tap water, $\mathrm{H}_{2} \mathrm{SO}_{4} \cdots \diamond$. Purified water, $\mathrm{H}_{2} \mathrm{SO}_{4}$

Fig.9 Elution concentration of molybdenum soak in dilute acid. Initial $\mathrm{pH}$ of the sample other than tap water and the purified water ware adjusted to three.
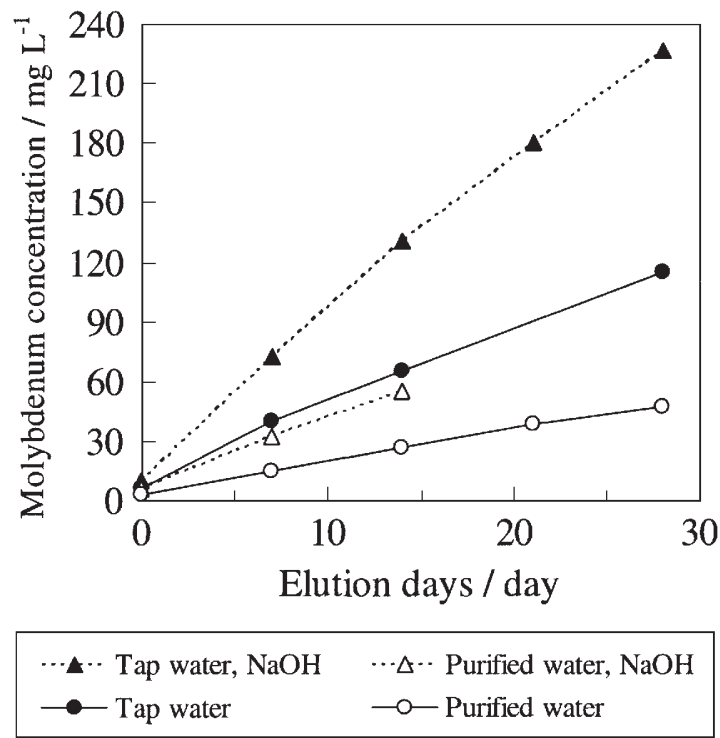

Fig.10 Elution concentration of molybdenum soak in dilute alkaline. Initial $\mathrm{pH}$ of the $\mathrm{NaOH}$ solution was adjusted to nine. 
に示した. 塩は $\mathrm{NaHCO}_{3}, \mathrm{Na}_{2} \mathrm{CO}_{3}, \mathrm{NaCl}, \mathrm{NaNO}_{3}, \mathrm{Na}_{2} \mathrm{SO}_{4}$, を準 備し, 各々 $1 \mathrm{mass} \%$ 投入した. 中性塩は若干の溶出抑制効果 があり, 塩基性塩には比較的溶出しやすい傾向が見られた。 炭酸水素ナトリウムの結果のみ初期から $28.8 \mathrm{mg} / \mathrm{L}$ の溶出があ り，2 週間後においても元の水道水よりも 2 倍近く溶出量が 增加していた. 酸化牏, 還元剤である $\mathrm{KMnO}_{4}, \mathrm{C}_{6} \mathrm{H}_{8} \mathrm{O}_{6}$ への溶 出結果をそれぞれ Fig.12に示した。酸化剂である過マンガン 酸カリウム $(1 \mathrm{~g} / \mathrm{L})$ においても, 還元剤であるアスコルビン酸 (0.1 vol\%)を用いてもいずれも大きな溶出抑制効果や溶出を促 進するなどの変化は見られなかった. むしろ過マンガン酸力 リウムにおいて，初期から $30 \mathrm{mg} / \mathrm{L}$ を超光る溶出があり，大 きな溶出の傾向がみられた. しかし,1ヶ月後にはその溶出が 収まる傾向にあり，溶出防止のためのメカニズムを考えるヒ ントになる可能性がある.

モリブデンの溶出抑制物質の検討を行った結果をFig.13に 示した. 溶出抑制物質としては $\mathrm{MnO}_{2}, \mathrm{CaCO}_{3}, \mathrm{CaCl}_{2}, \mathrm{ZnO}$, $\mathrm{Pb}\left(\mathrm{OCOCH}_{3}\right)_{2}$ を準備し, 各物質は $2 \mathrm{~g} / \mathrm{L}$ を溶液に投入した. 低 溶解度のモリブデン酸塩を構成する陽イオンを含んだ物質を 種々導入して調查した. 酢酸鉛 (II) 溶液では溶出が測定され ず， $\mathrm{CaCl}_{2}, \mathrm{ZnO}$ 溶液には純水よりも溶出しなかった，それぞ れの濃度は $0.2 \mathrm{vol} \%$ 水溶液とした。

モリブデンが水中に残存しないための吸着剤として鉛化合物 が有効であることが知られている7). 酶酸鈶(II) $\mathrm{Pb}\left(\mathrm{OCOCH}_{3}\right)_{2}$ において，著しい溶出抑制効果を得ることができたが，鉛化 合物をモリブデンの溶出防止のために混合することは現実的 ではない．また，溶出が抑制されているというよりも，内田 らワが示唆しているように, 水中でのモリブデンの鉛への吸 着が優先的に行われているものと考えられる. 混合工程では
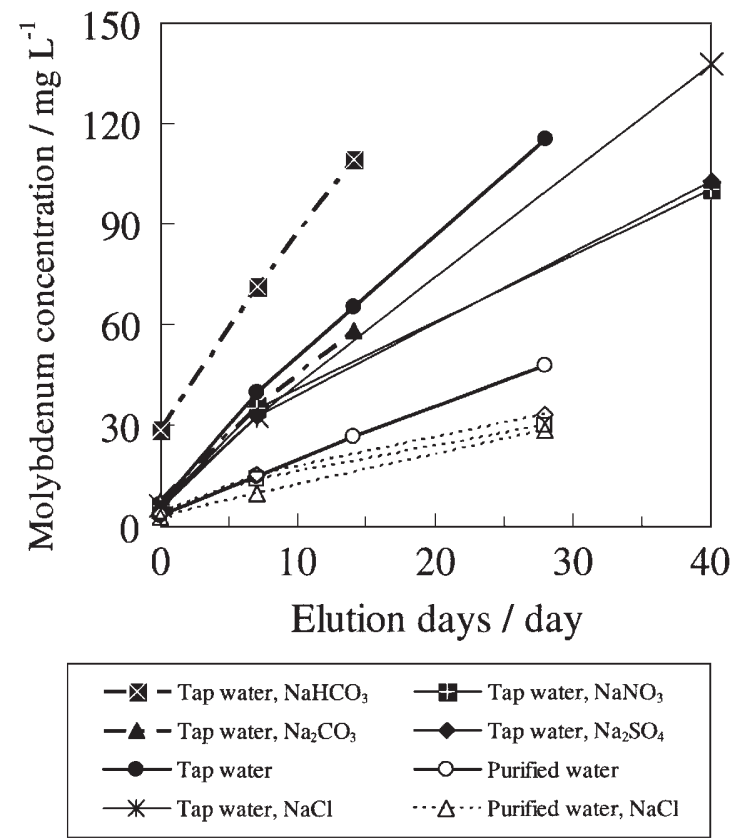

Fig.11 Elution concentration of molybdenum soak in 1 mass $\%$ dilute solt.
不純物を使用できないが，溶出のプロセスを今後検討し，そ のメカニズムから検討を行う予定である。

\section{5 まとめ}

本実験の結果を以下に示した.

(1) 小粒径および水温が高いほど溶出する。

(2) 水道水は純水に比して溶出が多い.

(3) モリブデンの溶出とともに $\mathrm{pH}$ は低下し，純水では1ヶ月 で 0.5 程度低下する.

(4) 金属モリブデン粉末(0価), $\mathrm{MoO}_{2}$ (4価)に比較すると $\mathrm{MoO}_{3}$ (6価)の溶出が大きく1ヶ月で $95 \%$ 溶出した.
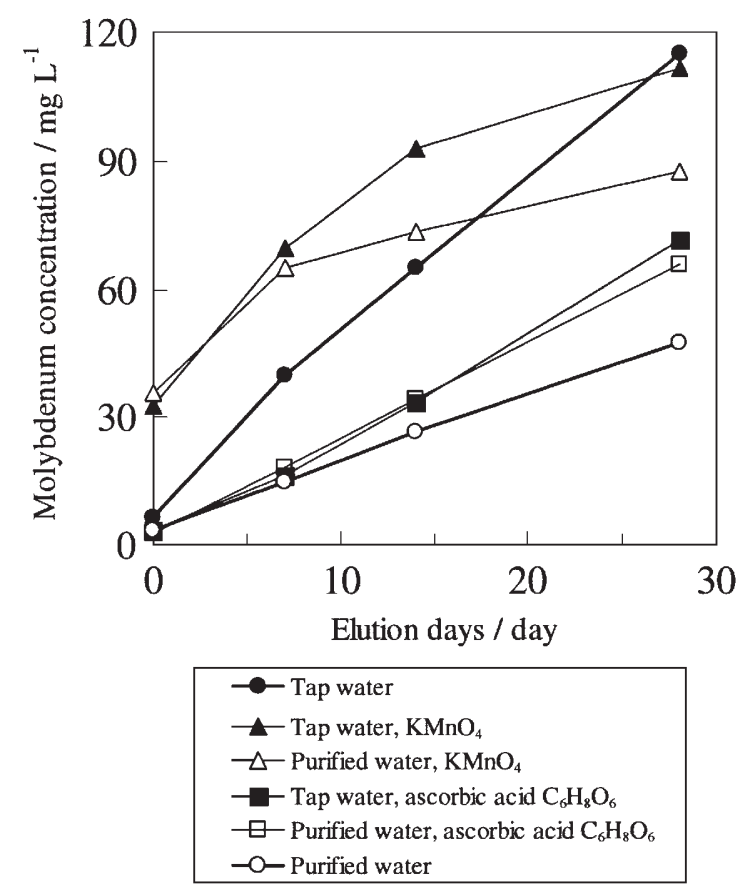

Fig.12 Elution concentration of molybdenum soak oxidizing and reducing agent in water.

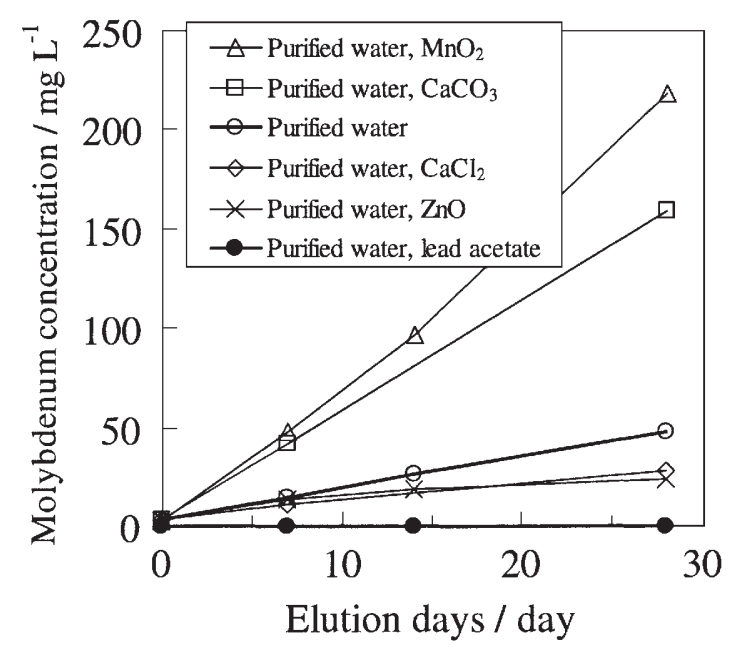

Fig.13 Elution concentration of molybdenum soak elution inhibiting material $2 \mathrm{~g}$ in 1 liter purified water. 
(5) 初期 $\mathrm{pH} 3$ の希酸に対しては溶出量は元の水道水の約 $2 / 3 に$ 低減でき, 初期 $\mathrm{pH} 9$ の希アルカリ $(\mathrm{NaOH})$ に対しては 2 倍 程度溶出しやすい.

（6）中性塩には溶出しにくく, 塩基性塩には比較的溶出しゃ すい。

(7) 酸化剤/還元剤の溶出量に大きな差はなく, 酢酸鉛 (II) 溶 液には全く溶出しなかった。

モリブデンへのドープ剂の混合を考光た場合, 通常のドー プ釜を使用する限りでは，閉鎖系で乾燥するため，系外から の影響を排除できる事からドープ比率が異なる心配はない． 但し, 溶出, 析出といった現象は本研究の目的である歩留低 下の原因となるモリブデン粉末を本来とは違う粒度に変える 可能性があるため, $\mathrm{MoO}_{3}$ 以外の酸化物または金属モリブデ ン粉末に純水を用いて, 高温にならない状態でドープするほ うがより安定した製造条件となる. 水道水を用いるべきでは ないことが確認できた. 現状, モリブデンの溶出を現状工程 にて抑制する物質を新たに加えることは必要ないが，上述の ような工程を選択していくことによって, より環境にやさし い処理工程になるであろう。

\section{謝辞}

本研究はタングステン・モリブデン工業会 (タンモリ工業 会)の分析専門委員会として取り組まれたものであり, 本研 究に理解を頂いた参加各社およびご協力頂いた関係各位に感 謝する。

\section{文献}

1) M. Endo, K. Kimura, T. Udagawa, S. Tanabe, and H. Seto: "The Effects of Doping Molybdenum Wire with Rare Earth Elements", $12^{\text {th }}$ International Plansee Seminar ' 89 proceedings, Reutte, 1 (1989)37-52.

2) C. Stallybrass, G. Leichtfried, and A. Kneissl: "Influence of the Dew Point of the Atmosphere on the Sintering of Doped Molybdenum", $15^{\text {th }}$ International Plansee Seminar '01 proceedings, Reutte, 1(2001)267-276.

3) H. Ueshima, A. Hoshika, and S. Hirata: "An Advanced Technique for Analysis of Toxic Substances in Polluted Soil (III)", Kankyo Hozen Kenkyuu Seikasyuu, 1997(1998)65-III-165-III-10.

4) I. Saito: "Studies on Oxidation, Reduction and Adsorption of Metallic Ions in Aqueous Solutions by Activated Carbons and the Like", Report of the National Research Institute for Pollution and Resources, 45(1989) 26-33.

5) T. Sugio, Y. Tsujita, T. Katagiri, K. Inagaki, and T. Tano: "Reduction of $\mathrm{Mo}^{6+}$ with Elemental Sulfur by Thiobacillus ferrooxidans", Journal of Bacteriology, 170(1988)5956-5959.

6) F.A. Cotton and G. Wilkinson: Advanced Inorganic Chemistry, 5th ed., John Wiley \& Sons, Inc., (1988)804-847.

7) A. Uchida, H. Koyanaka, S. Okubo, and T. Fujita: "Removal of Mo(VI) Ion from Waste Water with Lead Compounds", Shigento-Sozai, 118(2002)81-85. 